\title{
Ecology and Genetic Identification of Freshwater Turtles in Pakistan
}

\author{
Muhammad Qayash Khan', Yaseen', Hafsa Zahid', \\ Muhammad Numan', Itabajara da Silva Vaz Jr.®² \& Abid Ali ${ }^{1}$
}

\begin{abstract}
Background: The turtle population plays an important role in sustaining the water ecosystem by minimizing pollution from water. The identification and molecular investigation of freshwater fauna is essential for conservation of the species that are near to extinction. The quality of water, type of flora, fauna, and environmental condition are the major factors that directly affect the distribution of freshwater turtles. Two families including eight species of freshwater turtles are found in Pakistan. The Geoemydidae (Geoclemys hamiltonii, Hardella thurjii, Pangshura smithii, and Pangshura tecta) and Trionychidae (Chitra indica, Nilssonia gangetica, Nilssonia hurum, and Lissemys punctata andersoni). Studies on the species diversity and habitat of freshwater turtle have not been focused previously in the region. The present study was the first conducted to estimate the habitat and genetic diversity of freshwater turtles using 12S rRNA (ribosomal RNA) gene in Pakistan.

Materials, Methods \& Results: A total of 26 samples were collected from various localities using hand net, cast net, gills net, steel hooks, thick chemical wire, using chicken intestine and small fishes. The collected turtle specimens were morpho-taxonomically categorized into two genera, Lissemys punctata andersoni $(\mathrm{n}=13,50 \%)$ and Nilssonia gangetica $(\mathrm{n}=13,50 \%)$. The collected species showed an aggressive and active behavior in captivity during summer. Genomic DNA was extracted from collected specimens and used in PCR reaction by using specific primers for the amplification of short fragments of $12 \mathrm{~S}$ rRNA gene. Analysis of generated sequences confirmed the existence of L. p. andersoni in the region. The generated sequences of L. p. andersoni correspond to Clad A and showed a close resemblance among different species of the genus Lissemys.

Discussion: The climatic change such as temperature and rainfall have great effects on the occurrence of turtles. Habitat degradation occurred due to various factors such as draining wetlands, deforestation, converting clear water rivers to stagnant multi-purpose reservoirs and mortality on roads when turtles move around to feed. Current study concluded that the freshwater turtles L. p. andersoni and N. gangetica are interested in natural feeds. The analysis of $359 \mathrm{bp}$ of $12 \mathrm{~S}$ rRNA gene of the genus Lissemys turtles showed relationships of these turtles with cyclanorbines flap shell turtles, which agrees with previous reports. The African taxa are paraphyletic with respect to the Asian Lissemys. The ancestors of the extant genus cyclanorbines spread from North America to Asia [26]. It should be expected that each of the 3 taxa, L. p. andersoni, L. p. punctata and L. scutata represents a distinct genetic lineage. Present molecular investigation concluded that Clad A comprising $L$. p. punctata, L. scutata, L. cylonensis also include $L$. p. andersoni species. Clad B also contains one sequence from India, identified as L. p. andersoni. Their classification as conspecific evolutionary lineages are suggested by similar genetic divergences, the observation of mismatches between morphology (spotted vs. unspotted) and mitochondrial haplotypes in clades A and B. The clades A and B provides evidence for gene flow between the spotted subspecies $L$. $p$. andersoni and adjacent populations with unspotted flap shell turtles. This study is the first investigation about the habitat and of the endemic turtle species L. p. andersoni and N. gangetica in Pakistan. The genetic identification followed by phylogenetic analysis based on 12S rRNA partial genes revealed a closest similarity with the sequences generated for the same species from the neighboring countries. This study provided information to conduct further molecular studies that are essential to provide significant genetic data about turtle species.
\end{abstract}

Keywords: turtle, ecology, diversity, phylogeny, Pakistan.

DOI: $10.22456 / 1679-9216.113136$ 


\section{INTRODUCTION}

Freshwater turtles in muddy environments, medium-size rivers, dams, and ponds are considered as water purifiers as it contributes to the reduction of algal bloom and are indicators of pollution $[4,23,28,36]$. Soft-shell turtles are a useful source of protein $[11,17,37]$ and used for purifying blood and cure respiratory diseases and intestinal disorders $[13,24]$. Several factors such as habitat fragmentation, pollution, introduction of exotic species, hunting, and global climate change affect the biodiversity of turtle fauna $[5,9,19,21,22]$. The conservation and hatch and release programs of freshwater turtles was initiated in the last two decades for the purification of different freshwater bodies [16,25,31,32,37].

Two families including 8 species of freshwater turtles are found in Pakistan [2,3,15,17,31]. The Geoemydidae (Geoclemys hamiltonii, Hardella thurjii, Pangshura smithii, and Pangshura tecta) and Trionychidae (Chitra indica, Nilssonia gangetica, Nilssonia hurum, and Lissemys punctata andersoni). Lissemys is unique among all turtles due the peripheral bone and flexible rubbery posterior shell margin [6].

Pakistan banned the export of wild mammals and reptiles in 1981 and struggled for conservation and protection of threatened species. However, illegal trade of turtles and their body parts have been regularly reported $[1,15,16,18]$.

The harmful effects on freshwater turtles due to habitat destruction in Pakistan have been documented and mostly associated with anthropogenic activities [16,19,21,31]. Studies are scarce on the molecular identification and ecology of freshwater turtles in Pakistan. Therefore, present study aimed to investigate the ecology and molecularly identify these turtle species.

\section{MATERIALS AND METHODS}

Study area

The study was conducted in District Malakand namely Esaro Banda, Musamina, Roos Banda, Camp and Ghari Usmani Khel and specimens were collected during 2018-2019. A total of 5 sites were surveyed in the selected District. The Global Positioning System was used to obtain geographic coordinate data on a Microsoft Excel spreadsheet to create a map for the selected study areas using ArcGIS 10.3.1 (Figure 1).

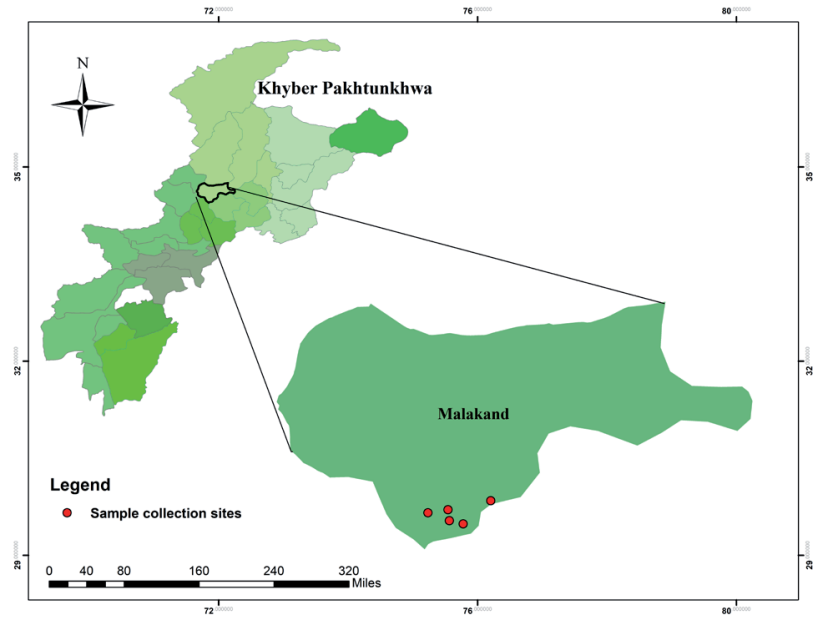

Figure 1. Map of Khyber Pakhtunkhwa (top), map of district Malakand, study area (bottom).

\section{Capturing}

The samples of freshwater turtles were captured by hand net, cast net, gills net, steel hooks, thick chemical wire, using chicken intestine and small fishes.

\section{Identification of the turtle}

The freshwater turtle species identification was based on standard published literature and keys $[12,14,17,32]$. The morphometry of turtles was carried out as described previously [33] based on carapace width $(\mathrm{CW})$, carapace length $(\mathrm{CL})$, plastron width (PW), plastron length (PL) and body weight (BW) [33].

\section{Turtle habitat and population}

Habitat preference of each freshwater turtle species was determined by field observation directly. Habitat types and water status in the targeted areas were recorded. The survey was conducted in morning time at 9 am to $2 \mathrm{pm}$ and at nighttime $9 \mathrm{pm}$ to $11 \mathrm{am}$ in winter as well as in summer. Mostly L. p. andersoni and N. gangetica species come out of water for basking at $11 \mathrm{am}$ to $1 \mathrm{pm}$ in different targeted sites. To estimate the total population of turtles, the adopted method [27] was followed in which accurate determination of the species was done.

The water and air temperature were recorded through the use of a mercury thermometer which is essential for the conservation. To determine the physicochemical parameters of water during field survey this data has been used to analyze the basking, ambient temperature and feeding activities. Physio-chemical parameters of water monitored each week for the period of one year in captivity. 
Study of ecological in captivity

Culture conditions were created with use of tanks with following dimensions: total length (TL) 9 , width 1.5 and height $1.2 \mathrm{~m}$, in Abdul Wali khan University Mardan (AWKUM), KP, Pakistan. Cemented tank was made with suitable space inside the boundary of the tank which was used for the turtle feeding and breeding behavior and observed on daily bases (Table 1). Weekly physico-chemical parameters of water were analyzed in the analytical chemistry laboratory of AWKUM (Table 2). Average parameters were recorded, and the data was analyzed statistically using one-way ANOVA.

\section{Blood sampling and DNA extraction}

First the weight of the sample was determined and then $1 \mathrm{~mL}$ of i.m. ketamine (ketasol) ${ }^{1}$ was injected and waited up to $10 \mathrm{~min}$ until complete anesthesia. Blood from the femoral vein through a $5 \mathrm{cc}$ sterilized syringe was taken in an EDTA tube and stored at $-20^{\circ} \mathrm{C}$.

A total of 13 morphologically identified samples of L. p. andersoni in the selected area were used for genomic DNA extraction through standard manual phenol chloroform method [30]. The concentration of DNA samples was quantified using a NanoDrop $^{\text {TM }}$ 2000/2000c Spectrophotometers ${ }^{2}$ and stored at $-20^{\circ} \mathrm{C}$ until further processing. Partial fragment of 12S rRNA gene for L. p. andersoni was amplified by PCR (HT, ILF, UK) using specific primers. PCR reaction was performed in a total volume of $20 \mathrm{~mL}$ reaction mixture with composition of $1 \mathrm{~mL}$ of each forward (TACAAAAATATCCGCCAGAAAAC) and reverse primer (CTCAGGTC CGGTTTTAATTG), 2
$\mathrm{mL}$ of template DNA (100 ng), $4 \mathrm{~mL}$ of deionized water and $12 \mathrm{~mL}$ of master mix (DreamTaq PCR Master Mix [2X]2. The thermocycling conditions for reaction were optimized as $5 \mathrm{~min}$ at $95^{\circ} \mathrm{C}$ for initial denaturation followed by 40 cycles of denaturation at $95^{\circ} \mathrm{C}$ for $30 \mathrm{~s}$ annealing at $60^{\circ} \mathrm{C}$ for $30 \mathrm{~s}$, and extension at $72^{\circ} \mathrm{C}$ for $1 \mathrm{~min}$, and final extension for $10 \mathrm{~min}$ at $72^{\circ} \mathrm{C}$. PCR products were confirmed by running $2 \%$ ethidium bromide-stained agarose gel with a $50 \mathrm{bp}$ DNA marker ${ }^{2}$. The results were visualized using the GelDoc $^{3}$.

\section{DNA purification and sequencing}

The amplified PCR products were purified with the GeneClean II kit ${ }^{4}$ according to the manufacturer's instructions. The purified PCR amplicons (13 PCR product samples) were sequenced unidirectionally by Macrogen ${ }^{5}$. The obtained sequences were trimmed using SeqMan V 5.0 (DNASTAR ${ }^{6}$ ) to remove poor quality sequences and further analyzed by using BioEdit Sequence Alignment Editor V. 7.0.57 [10] and subjected to BLAST (Basic Local Alignment Search Tool) at NCBI (National Center for Biotechnology Information) to collect the relevant sequences of closely related with the species of L. p. andersoni available in GenBank.

\section{Phylogenetic analysis}

The obtained trimmed sequences were aligned using ClustalW in BioEdit V 7.0.5 [10]. The phylogenetic tree for $12 \mathrm{~S}$ rRNA sequences were generated based on the maximum likelihood method in MEGA$\mathrm{X}^{8}$, with 1000 bootstrapping [20].

Table 1. Feeding habit and behavior of freshwater turtles in captivity.

\begin{tabular}{|c|c|c|c|}
\hline Species & Habitat & Food & Behavior \\
\hline $\begin{array}{c}\text { Lissemys punctate } \\
\text { andersoni }\end{array}$ & $\begin{array}{l}\text { Shallow pools, lakes, } \\
\text { rivers, stream, ponds, rich } \\
\text { flora, less fauna }\end{array}$ & $\begin{array}{c}\text { carnivore/herbivore: } \\
\text { Anura, Blattodea, Hirudinea, Anisoptera, and plants, Mentha longifolia, } \\
\text { arundo donax, Origanum vulgare, Cynodon dactylon, Convolvulus } \\
\text { arvense, Desmostachya bipinnata , Channa gachua, Bufo surdus, } \\
\text { Lumbricina }\end{array}$ & $\begin{array}{l}\text { Shy and } \\
\text { aggressive }\end{array}$ \\
\hline Nilssonia gangetica & $\begin{array}{c}\text { River, lakes, permanent } \\
\text { ponds, rick fauna and } \\
\text { flora. }\end{array}$ & $\begin{array}{c}\text { Omnivore: } \\
\text { Glyptothorax slocki, Tor putitora, Channa punctatus, Channa gachua, } \\
\text { Bufo surdus, Lumbricina, Mastacembelus armatus } \\
\text { Anas, Gallus gallus domesticus, Blattodea, Anisoptera and plant like } \\
\text { Amaranthus viridis, Cynodon dactylon, Dalbergia sissoo, Desmostachya } \\
\text { bipinnata, Ficus carica, Medicago minima, Tribulus terrestris, }\end{array}$ & $\begin{array}{c}\text { Very } \\
\text { aggressive }\end{array}$ \\
\hline
\end{tabular}


Table 2. Physico-chemical parameters of water in freshwater turtles' captivity.

\begin{tabular}{ccccccc}
\hline Time Duration & Conductivity $(\mathrm{ms} / \mathrm{cm})$ & Salinity $(\mathrm{g} / \mathrm{L})$ & $\mathrm{pH}$ & Resistivity & TDS $(\mathrm{mg} / \mathrm{L})$ & Water temp $\left({ }^{\circ} \mathrm{C}\right)$ \\
\hline Initial First Week & $3.01 \pm .015$ & $0.385 \pm .0025$ & $7.77 \pm .020$ & $1.57 \pm .375$ & $0.25 \pm .020$ & $22 \pm 2.00$ \\
Final First Week & $2.87 \pm .020$ & $0.185 \pm .003$ & $6.8 \pm .100$ & $1.58 \pm .375$ & $5.04 \pm .020$ & $25 \pm 1.00$ \\
Initial Second Week & $3.02 \pm .020$ & $0.384 \pm .003$ & $7.77 \pm .020$ & $1.58 \pm .369$ & $0.26 \pm .020$ & $23 \pm 1.00$ \\
Final second Week & $2.8 \pm .100$ & $0.177 \pm .002$ & $6.6 \pm .200$ & $4.92 \pm 6.128$ & $5.02 \pm .010$ & $26 \pm 1.00$ \\
Initial third Week & $2.8 \pm .100$ & $0.385 \pm .002$ & $7.76 \pm .030$ & $1.37 \pm .020$ & $5.02 \pm .020$ & $21 \pm 2.00$ \\
Final third Week & $2.8 \pm .100$ & $0.186 \pm .002$ & $6.5 \pm .200$ & $1.98 \pm .015$ & $5.02 \pm .010$ & $27 \pm 2.00$ \\
Initial fourth Week & $2.8 \pm .100$ & $0.385 \pm .003$ & $7.77 \pm .020$ & $1.58 \pm .363$ & $5.02 \pm .02$ & $23 \pm 2.00$ \\
Final fourth Week & $2.8 \pm .000$ & $0.176 \pm .002$ & $6.4 \pm .200$ & $1.97 \pm .015$ & $5.02 \pm .020$ & $25 \pm 2.00$ \\
\hline
\end{tabular}

\section{RESULTS}

The census observed two species of turtle L. p. andersoni and $N$. gangetica. The targeted station was covered by grassy vegetation. It included such as mud content, hard soil, shallow water, and sandy rocky bank. All collected species belong to the family Trionychidae. The abundant population of L. p. andersoni was observed in river Camp (26.92\%) while L. p. andersoni was absent in Musamina persh and Ross banda. The abundant population of $N$. gangetica was observed in Ross banda $23.07 \%$ and near camp and Ghari Usmanikhel were found free of $N$. gangetica. The locality of Esaro banda had both species $(19.23 \%)$ where the area was covered by muddy soil and huge amounts of fauna and flora. During the survey, recorded water and air temperature was $30-43.88^{\circ} \mathrm{C}$, conductivity $720-824$ (ms/cm), pH 7.6-8, resistivity 1.30 - 1.37, TDS 350 $410(\mathrm{mg} / \mathrm{L})$ and salinity $0.35-0.42 \mathrm{~g} / \mathrm{L}$. The highest number of turtles were recorded in summer session.

The $\mathrm{C} / \mathrm{L}, \mathrm{W}, \mathrm{P} / \mathrm{L}, \mathrm{W}$ and TL range of $L . p$. andersoni recorded $0.1217-0.383 \mathrm{~m}$ while the $N$. gangetica range $0.253-0.7114 \mathrm{~m}$. The ratio of body weight $L$. p. andersoni $0.19-1.89 \mathrm{~kg}$ and $N$. gangetica $6.30-12.38 \mathrm{~kg}$. In tank first The L. p. andersoni were consumed differently 4 animals and 9 plants. The $N$. gangetica were able to consume 12 animals and 6 plants. The L. p. andersoni showed shy and aggressive behavior while $N$. gangetica were extremely aggressive in behavior from April to September in cemented tanks especially in summer from 11am - 3pm (Table 1).

Habitat composition varied considerably among the targeted sites depending on the nature of banks and availability of fauna and flora. From June to August the turtle's habitat degraded heavy rainfall and major flood following dislodged and inundated most of our water level monitoring stations. Major sources of water come out from ground and also contaminated water with sewage coming from shop houses and institutes, water as polluted.

\section{Sequence and phylogenetic analysis}

Thirteen nucleotide sequences with $359 \mathrm{bp}$ were obtained in this work and showed $100 \%$ identity in nucleotide sequence. A total of 44 similar sequences of turtle 12S rRNA gene were downloaded from NCBI. Comparative analysis of a current sequence showed 99$100 \%$ identity in nucleotide sequence, with $12 \mathrm{~S}$ rRNA sequences reported from India (FR850504, MF041983, FR850529, FR850513, FR850522) and Sri Lanka (FR850544). Sequences generated in this study were deposited to the GenBank (MT000050). In phylogenetic analyses, the sequence from Pakistan was clustered with L. p. andersoni from India and Sri Lanka (Figure 2).

\section{DISCUSSION}

The present study investigated the ecology and molecular phylogeny of freshwater turtles in Pakistan. The turtles were reared in captivity for one year and the water parameters were checked thoroughly. Studies are conducted on ecology and genetic diversity of freshwater turtles while attempting to address strategies for turtle's conservation poses a problem. The Indian flap-shell turtle is an abundant species, due to its affections to stagnant waters of rivers, ponds, shallow streams, lakes, marshes and extends into the urban sewage system. The $N$. gangetica were abundant with a reasonable population in all surveyed sites [28,35,31]. As far as the present study reported that L. p. andersoni and $N$. gangetica are found in the drain system, stagnant water, canal, and stream at target sites. 


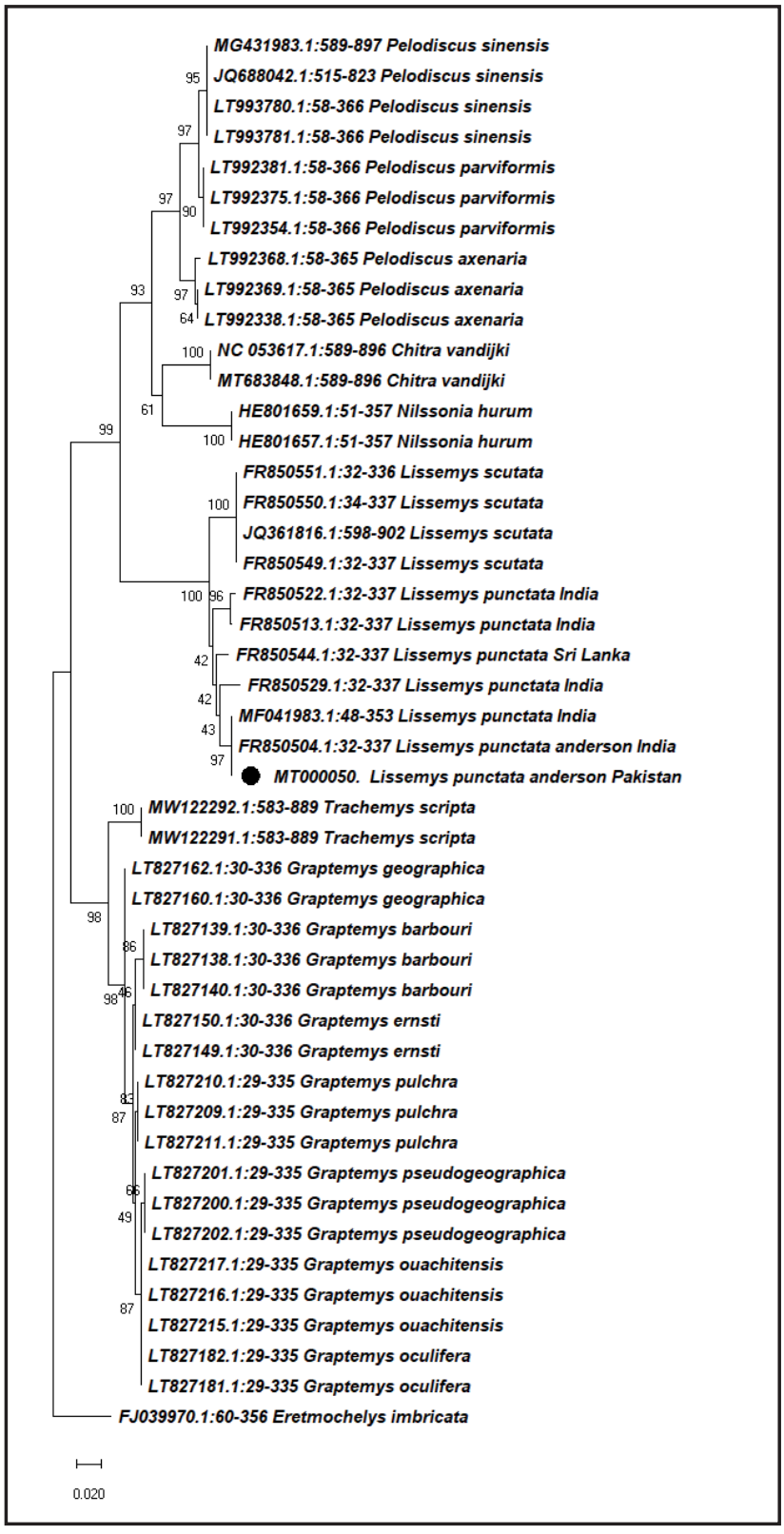

Figure 2. Maximum likelihood analyses inferred from $12 \mathrm{~S}$ rRNA sequences from the genus Lissemys and Eretmochelys imbricata were used as an outgroup. GenBank accession numbers are followed by species name and location of collection. Support values (Bootstrapping values) were indicated at each node. The bar represents 0.020 substitutions per site. Obtained sequences has been represented by black dot.

The climatic change such as temperature and rainfall have great effects on the occurrence of turtles. Habitat degradation occurred due to various factors such as draining wetlands, deforestation, converting clear water rivers to stagnant multi-purpose reservoirs and mortality on roads when turtles move around to feed [34]. Food habitats will be helpful for potential farmers to manage their farms in the most effective and natural way [38]. Current study concluded that the freshwater turtles L. p. andersoni and N. gangetica are interested in natural feeds.
The analysis of $359 \mathrm{bp}$ of 12S rRNA gene of the genus Lissemys turtles showed relationships of these turtles with cyclanorbines flap shell turtles, which agrees with previous reports [7,26]. The African taxa are paraphyletic with respect to the Asian Lissemys. The ancestors of the extant genus cyclanorbines spread from North America to Asia [26]. It should be expected that each of the 3 taxa, L. p. andersoni, L. p. punctata and $L$. scutata represents a distinct genetic lineage [3,6-8,26]. Present molecular investigation concluded that Clad A comprising L. p. punctata, L. scutata, L. cylonensis also include L. p. andersoni species. Clad B also contains one sequence from India, identified as L. p. andersoni. Their classification as conspecific evolutionary lineages are suggested by similar genetic divergences, the observation of mismatches between morphology (spotted vs. unspotted) and mitochondrial haplotypes in clades A and B. The clades A and B provides evidence for gene flow between the spotted subspecies L. p. andersoni and adjacent populations with unspotted flap shell turtles. This molecular investigation will contribute to a better understanding in the systematics and taxonomy of freshwater turtles.

\section{CONCLUSION}

This study explored the ecology, habitat and diversity of freshwater turtles at molecular level in Pakistan. Two species of turtle, L. p. andersoni and N. gangetica were reported from the selected region. It was the first study that molecularly characterized important turtle species, L. p. andersoni, in Pakistan. The phylogeny of $12 \mathrm{~S}$ rRNA showed similarity with $L$. p. andersoni from other Asian regions. Finally, this study provided the foundation to conduct further molecular studies that are essential to explore the genetic diversity of turtle species.

\section{MANUFACTURERS}

${ }^{1}$ Indus pharma. Karachi, Pakistan.

${ }^{2}$ Thermo Fischer Scientific Inc. Waltham, MA, USA.

${ }^{3}$ UVP, BioDoc-it ${ }^{\mathrm{TM}}$. Upland, CA, USA.

${ }^{4}$ QBIOGENE Inc. Carlsbad, CA, USA.

${ }^{5}$ Macrogen. Seoul, South Korea.

${ }^{6}$ DNASTAR Lasergene Inc. Madison, WI, USA.

${ }^{7}$ BioEdit North Carolina State University. Raleigh, NC, USA.

${ }^{8}$ Institute of Molecular Evolutionary Genetics Analysis (MEGA). State College, PA, USA.

Acknowledgements. The authors are grateful to Pakistan Science foundation and Higher Education Commission Pakistan for providing financial support for ongoing research in the laboratory. 
Ethical approval. The present study was approved by the advance studies and research board of the Abdul Wali Khan University Mardan (Dir/A\&R/AWKUM/2020.4871).
Declaration of interest. The authors certify that they have no affiliations with, or involvement in any organization or entity with any financial interest in the subject matter or materials discussed in this manuscript.

\section{REFERENCES}

1 Ali W., Javid A., Hussain A. \& Bukhari S.M. 2018. Diversity and conservation of freshwater turtles in Pakistan: a review. Biodiversity. 19(1-2): 62-71.

2 Begum A., Khan M.Z., Ghalib S.A., Kanwal R., Zehra A., Yasmeen G., Siddiqui S., Hussain B., Khan I.S., Safi A. \& Usman M. 2016. Distribution, status and current trends in the population of coastal birds of Balochistan. Canadian Journal of Pure and Applied Science. 10(2): 3853-3864.

3 Bibi F. \& Ali Z. 2013. Measurement of diversity indices of avian communities at Taunsa Barrage Wildlife Sanctuary, Pakistan. The Journal of Animal and Plant Sciences. 23(2): 469-474.

4 Brito E.S., Strüssmann C., Kawashita-Ribeiro R.A., Morais D.H., Ávila R.W. \& Campos V.A. 2012. New records and distribution extensions of three species of Mesoclemmys Gray, 1863 (Testudines: Chelidae) in Mato Grosso state, Brazil, with observations on terrestrial movements. Check List: Journal of Species Lists and Distribution. 8(2): 294-297.

5 Brito E.S., Vogt R.C., Valadao R.M., Franca L.F., Penha J. \& Strüssmann C. 2018. population ecology of the freshwater turtle Mesoclemmys vanderhaegei (testudines: Chelidae). Herpetological Conservation and Biology. 13(2): 355-365.

6 Delfino M., Scheyer T.M., Fritz U. \& Sanchez-Villagra M.R. 2010. An integrative approach to examining a homology question: shell structures in soft-shell turtles. Biological Journal of the Linnean Society. 99(2): 462-476.

7 Engstrom T.N., Shaffer H.B. \& McCord W.P. 2004. Multiple data sets, high homoplasy, and the phylogeny of softshell turtles (Testudines: Trionychidae). Systematic Biology. 53(5): 693-710.

8 Fritz U., Gong S., Auer M., Kuchling G., Schneeweiß N. \& Hundsdörfer A.K. 2010. The world's economically most important chelonians represent a diverse species complex (Testudines: Trionychidae: Pelodiscus). Organisms Diversity \& Evolution. 10(3): 227-242.

9 Gibbons J.W., Scott D.E., Ryan T.J., Buhlmann K.A., Tuberville T.D., Metts B.S., Greene J.L., Mills T., Leiden Y., Poppy S. \& Winne C.T. 2000. The Global Decline of Reptiles, Déjà Vu Amphibians: Bioscience. 50(8): 653-666.

10 Hall T., Biosciences I. \& Carlsbad C. 2011. BioEdit: an important software for molecular biology. GERF Bulletin of Biosciences. 2(1): 60-61.

11 Hossain M.L., Sarker S.U. \& Sarker N.J. 2008. Ecology of Spotted Flap shell Turtle, Lissemys punctata (Lacepede, 1788) in Bangladesh. Ecoprint: An International Journal of Ecology. 15: 59-67.

12 Kanwal R., Khan M.Z., Kanwal R. \& Ghalib S.A. 2018. Distribution, status and conservation of freshwater turtles in the Selected Areas of Sindh. Journal of Animal and Plant Sciences. 28(3): 915-926.

13 Kayani S.B., Anwar M., Ashfaq M., Hussain I. \& Mahmood T. 2015. Morphometric studies of the freshwater turtles from Rawalpindi Islamabad Region of Pakistan. Journal of Biodiversity and Environmental Sciences. 6(5): 228-233.

14 Khan M.Q., Anjum M.Z., Adnan M., Khan A., Zahid H., Nawab J., Safi S.Z., Shah M.I.A., Kamil A. \& Ali A. 2020. Genetic Diversity of Schizothorax, Tor, and Mystus spp. in Khyber Pakhtunkhwa, Pakistan: Species of Economic Importance. Pakistan Journal of Zoology. 53(3): 1-11.

15 Khan M.S. 2004. Annotated checklist of amphibians and reptiles of Pakistan. Asiatic Herpetological Research. 10: 191-201.

16 Khan M.S. 2010. Checklist of amphibians of Pakistan. Pakistan Journal of Wildlife. 1(2): 37-42.

17 Khan M.Z., Kanwal R., Ghalib S.A., Fatima F., Zehra A., Siddiqui S., Yasmeen G., Safi A., Hashmi M.U.A., Hussain B. \& Iqbal M.A. 2016. A review of distribution, threats, conservation and status of freshwater turtles in Sindh. Canadian Journal of Pure and Applied Sciences. 10(3): 3997-4009.

18 Khan M.Z., Safi A., Ghalib S.A. \& Kanwal R. 2016. Population status, distribution and conservation of freshwater turtles of Peshawar valley, Khyber Pakhtunkhwa, Pakistan. Canadian Journal of Pure and Applied Sciences. 10(1): 3732-3750.

19 Khan S., Ali S., Muhammad S., Khan B., Ali A., Hesham E.L. \& Begum S. 2020. Bacterial contamination in drinking water of urban Peshawar: a comparative study at the sources and user points of tube wells. Desalination and Water Treatment. 181: 221-227. 
20 Kumar S., Stecher G., Li M., Knyaz C. \& Tamura K. 2018. MEGA X: molecular evolutionary genetics analysis across computing platforms. Molecular Biology and Evolution. 35(6): 1547-1549.

21 Liu M., Xu Y., Nawab J., Rahman Z., Khan, S., Idress M., Ali A., Ahmad R., Khan S.A., Khan A. \& Khan M.Q. 2020. Contamination features, geo-accumulation, enrichments and human health risks of toxic heavy metal (loids) from fish consumption collected along Swat river, Pakistan. Environmental Technology \& Innovation. 17: 100554.

22 Luiselli L. 2003. Comparative abundance and population structure of sympatric Afrotropical tortoises in six rainforest areas: the differential effects of "traditional veneration" and of "subsistence hunting" by local people. Acta Oecologica. 24(3): 157-163.

23 Marques T.S., Lara N.R., Bassetti L.A., Ferronato B.O., Malvásio A. \& Verdade L.M. 2013. Population structure of Mesoclemmys vanderhaegei (Testudines, Chelidae) in a silvicultural system in southeastern Brazil. Herpetology Notes. 6(1): 179-182.

24 Martins S., Rocha F., Rodrigues E., Lopes S.A., Abella E., Loureiro N.S. \& Marco A. 2015. The use of sea turtles in traditional medicine in the Cape Verde Archipelago, West Africa. African Sea Turtle Newsletter. 4: 12-15.

25 Narain S., Tripathi A. \& Mishra S.B. 2006. Population ecology of a freshwater turtle Kachuga tentoria near Panchnada (Etawah: U. P.) and its role as water purifier. Journal of Environmental Biology. 27(3): 589-596.

26 Praschag P., Stuckas H., Paeckert M., Maran J. \& Fritz U. 2011. Mitochondrial DNA sequences suggest a revised taxonomy of Asian flapshell turtles (Lissemys Smith, 1931) and the validity of previously unrecognized taxa (Testudines: Trionychidae). Vertebrate Zoology. 61(1): 147-160.

27 Rhodin A.G., Stanford C.B., Van Dijk P.P., Eisemberg C., Luiselli L., Mittermeier R.A., Hudson R., Horne B.D., Goode E.V., Kuchling G. \& Walde A. 2018. Global conservation status of turtles and tortoises (order Testudines). Chelonian Conservation and Biology. 17(2): 135-161.

28 Safi A. \& Khan M.Z. 2014. Distribution and current population status of freshwater turtles of District Charsadda of Khyber Pakhtunkhwa, Pakistan. Journal of Zoological Studies. 1(4): 31-38.

29 Salam A., Ali M., Khan B.A. \& Rizvi S. 2000. Seasonal changes in physico-chemical parameters of river Chenab Muzaffar Garh, Punjab, Pakistan. Journal of Biosciences. 4: 299-301.

30 Sambrook J. \&Russell D.W. 2001. Molecular Cloning: a Laboratory Manual. New York: Cold Spring Harbor Laboratory Press, pp.23-44.

31 Sarwar M.G., Abbas F.I. \& Shahjehan I.A. 2015. Distribution and Habitat Analysis for Freshwater Turtles of River Indus and some of its Tributaries in Khyber Pakhtunkhwa and Punjab, Pakistan. Journal of Bioresource Management. 2(3): 8.

32 Sial N., Haider M.K., Shahzad M.I., Abdullah M., Malik S., Tabasum S., Mustafa G., Azam S.M. \& Iqbal H. 2016. Feeding behavior of freshwater turtle (Pangshura smithii) with respect to seasonal temperature variations. Ciência e Técnica Vitivinícola. 31(6): 254-223.

33 Singh L.A.K. 1985. Nots on tracking and terrestrial activities of the freshwater turtle Kachuga tentoria in River Mahanadi, Orissa. Journal of the Bombay Natural History Society. 82: 414-417.

34 Stanford C.B., Iverson J.B., Rhodin A.G., Van Dijk P.P., Mittermeier R.A., Kuchling G., Berry K.H., Bertolero A., Bjorndal K.A., Blanck T.E. \& Buhlmann K.A. 2020. Turtles and tortoises are in trouble. Current Biology. 30(12): R721-R735.

35 Tariq M., Siddiq M.K., Muhammad R. \& Nadeem M.S. 2012. Distribution and relative abundance of freshwater turtles in Korang River Islamabad-Rawalpindi, Pakistan. Pakistan Journal of Zoology. 44(3): 889-893.

36 Vinke T., Vinke S. \& Kohler G. 2013. What is known about Mesoclemmys vanderhaegei (Bour, 1973): a systematic review of the available literature. Paraquaria Natural. 1(2): 21-31.

37 Weisrock D.W. \& Janzen F.J. 2000. Comparative molecular phylogeography of North American softshell turtles (Apalone): implications for regional and wide-scale historical evolutionary forces. Molecular Phylogenetics and Evolution. 14(1): 152-164.

38 Yousaf S. \& Mahmood T. 2018. Feeding Ecology of Four Freshwater Turtle Species in Pothwar Plateau and its Potential Implication in Turtle Farming in Pakistan. International Journal of Agriculture and Biology. 20(4): 723-729. 